\title{
The view of parents and teachers about the occurrence of deleterious oral habits in a group of preschool children
}

\author{
Denise Maria Zaratini Fernandes ${ }^{1}$ \\ https://orcid.org/0000-0003-3973-9032 \\ Maria Cecília Marconi Pinheiro Lima² \\ https://orcid.org/0000-0002-4203-0019
}

Universidade Estadual de Campinas UNICAMP, Faculdade de Ciências Médicas, Programa de Pós-Graduação em Saúde, Interdisciplinaridade e Reabilitação, Campinas, São Paulo, Brasil.

${ }^{2}$ Universidade Estadual de Campinas UNICAMP, Departamento de Desenvolvimento Humano e Reabilitação, Campinas, São Paulo, Brasil.

Conflict of interests: Nonexistent

\section{(c) (i)}

Received on: September 28, 2018 Accepted on: February 7, 2019

Corresponding address:

Denise Maria Zaratini Fernandes Rua Antônio Sachi, 351 bloco Magnólia

apto 11, Chácara da Barra

CEP: 13090-751 - Campinas -

São Paulo - Brasil

E-mail: denise_zaratini@yahoo.com.br

\section{ABSTRACT}

Objective: to compare the parents and teachers views about the occurrence of deleterious oral habits in preschool children.

Methods: a cross - sectional study with a quantitative analysis. Parents and teachers answered a self-administered questionnaire regarding the deleterious habits of preschool children and signed the Informed Consent Term. At the end, 221questionaries were included. The data were submitted to Chi-square test, Fisher exact and McNemar tests.

Results: according to the parents, the most frequent habit was the bottle with $52.04 \%$, followed by the pacifier with $24.09 \%$. According to the teachers, the pacifier was the most frequent one, accounting for $20.36 \%$ of cases, followed by the use of bottle (7.69\%). In the present sample, $90.95 \%$ of the children were breastfed. When related to oral habits, it was observed that the longer the breastfeeding time, the lower the use of pacifiers and bottles. By comparing the questionnaires, it was verified that the parents noticed, more frequently, the oral habits than did the teachers.

Conclusion: in the group studied, the parents reported more the presence of deleterious oral habits than did the teachers. It is important that parents, and especially teachers, have information about the harm caused by the prolonged presence of such habits, so that they can encourage their interruption, thus, avoiding possible damages to the stomatognathic system and the performance of orofacial functions.

Keywords: Habits; Child, Preschool; Pacifiers; Nursing Bottle 


\section{INTRODUCTION}

Oral habits can be classified as normal or deleterious. Nasal breathing, chewing and swallowing are regarded as physiological and functional habits, since they contribute to the establishment of a normal occlusion, favoring the harmonic facial growth without deviations ${ }^{1}$. However, digital suction, oral breathing, use of pacifiers and bottles as well as, lower lip interposition/suction, tongue suction, onychophagy, and mandibular propulsion are considered deleterious oral habits ${ }^{2,3}$.

When persistent, these habits contribute to the development of malocclusions and phonetic changes, as they affect the growth and development of the muscles and bones of the jaw ${ }^{3,4}$.

It is known that breastfeeding meets the nutritional and emotional needs of the child, besides providing the correct development of orofacial structures, favoring chewing, swallowing, speech and breathing ${ }^{5}$.

It can be noticed that children who were not breastfed or who were not satisfactorily breastfed in the first six months of life tend to acquire deleterious oral habits with greater ease and for a longer period ${ }^{6}$.

Some parents understand that the use of pacifiers is harmless or even necessary and beneficial for the development of the child, thus they have an indifferent or permissive attitude towards its use ${ }^{7}$. However, the use of pacifiers and bottle feeding may cause speech disorders, myofunctional disorders and emotional difficulties $^{8}$. Oral habits are common in preschool children, as they occur in the early stages of life, since some objects, such as the pacifier, are included in the layette of pregnant women ${ }^{9}$.

For this reason, it is common to observe children entering institutions of early childhood education carrying such objects, and/or already with other oral habits. Educators often find it difficult to deal with children in the classroom in order to remove their oral habits, even if they are not aware of the harm caused by its prolonged use. Therefore, it is necessary to understand the perspective of parents and teachers on the presence of deleterious oral habits, thus enabling the conduction of health prevention and promotion actions in the first years of life, both in the family and school environment.
Thus, knowing the importance of the school and the participation of parents and teachers in the development of children's language and in the awareness of the prolonged use of oral habits, this study aims to compare the parents and teachers perspective on the occurrence of deleterious habits in preschool children.

\section{METHODS}

This is a cross-sectional study with quantitative analysis and it was approved by the Research Ethics Committee (CEP) of the Universidade Estadual de Campinas under the no. 1887842 in January 10, 2017. The sample was characterized as non-probabilistic for convenience.

391 parents of pre-school children aged 2 to 5 years old and 8 teachers who teach in a kindergarten program of a public educational institution located in the state of São Paulo were invited to participate. The voluntary participation of parents of the entire child population of the institution was an inclusion criterion, Free and Informed Consent Term (FICT) also should be read and signed by them and by all the teachers who work with the children. Exclusion criteria included children diagnosed with neurological syndromes, sensory impairment, autism, who used psychotropic medication, and/or who were in a diagnostic investigation process, as well as those whose parents did not sign the FICT.

A self-administered questionnaire that was elaborated by the researchers themselves and based on literature review was used as a research tool ${ }^{10-12}$. The questionnaire provided to parents and teachers consisted of 29 questions, including data on pregnancy/ childbirth, breast-feeding and deleterious oral habits, hearing complaints and oral language development. Questions regarding hearing complaints, as well as language development, were not used for analysis in this study. The questionnaire provided for teachers had the same questions regarding oral habits, feeding habits and breathing pattern of the questionnaire provided for parents. Figure 1 shows the questionnaire designed by the authors with the questions related to deleterious oral habits that was provided to the parents, while Figure 2 shows the questionnaire provided to the teachers. 


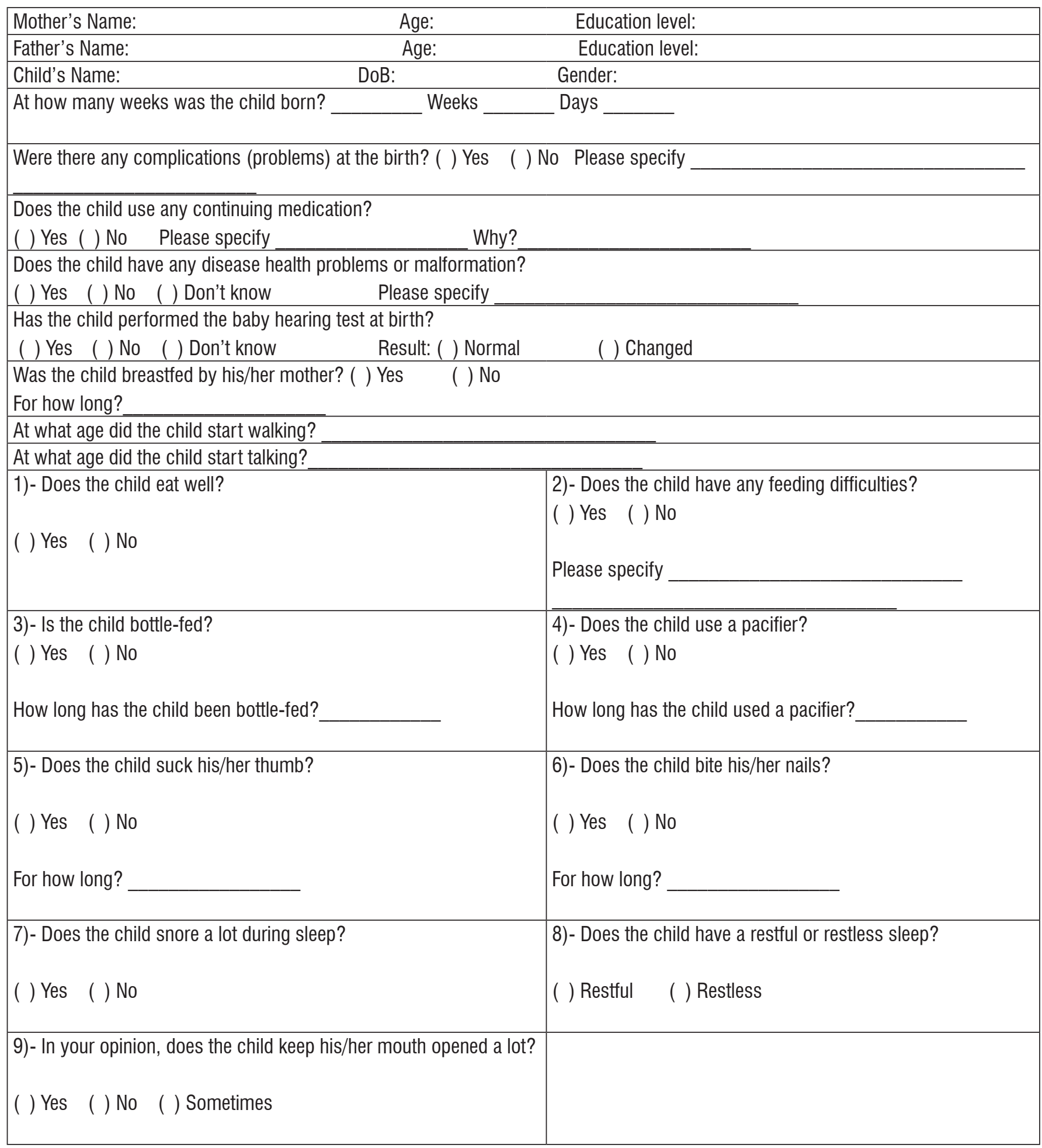

Based on the literature ${ }^{10-12}$

Figure 1. Questionnaire provided to parents 


\begin{tabular}{|c|c|}
\hline $\begin{array}{l}\text { Child's Name: } \\
\text { DoB: }\end{array}$ & AG: \\
\hline $\begin{array}{l}\text { 1)- Does the child eat well? } \\
\begin{array}{lll}\text { ( ) Yes } & \text { ( ) No }\end{array}\end{array}$ & $\begin{array}{l}\text { 2)- Does the child have any feeding difficulties? } \\
\text { ( ) Yes ( ) No } \\
\text { Please specify }\end{array}$ \\
\hline $\begin{array}{l}\text { 3)- Is the child bottle-fed? } \\
\text { ( ) Yes ( ) No } \\
\text { How long has the child been bottle-fed? }\end{array}$ & $\begin{array}{l}\text { 4)- Does the child use a pacifier? } \\
\text { ( ) Yes ( ) No } \\
\text { How long has the child been bottle-fed? }\end{array}$ \\
\hline 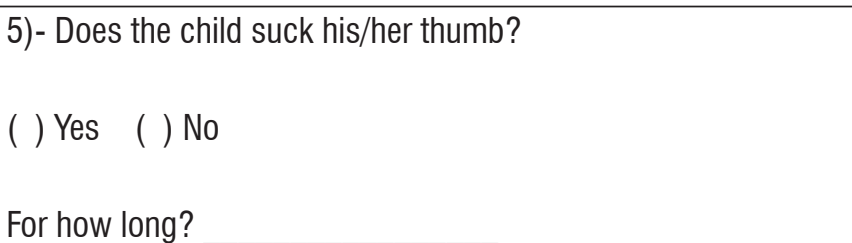 & $\begin{array}{l}\text { 6)- Does the child bite his/her nails? } \\
\text { ( ) Yes ( ) No }\end{array}$ \\
\hline $\begin{array}{l}\text { 7)- Does the child snore a lot during sleep? } \\
\begin{array}{ll}\text { ( ) Yes } \quad \text { ( ) No }\end{array}\end{array}$ & $\begin{array}{l}\text { 8)- Does the child have a restful or restless sleep? } \\
\begin{array}{ll}\text { ( ) Restful } & \text { ( ) Restless }\end{array}\end{array}$ \\
\hline $\begin{array}{l}\text { 9)- In your opinion, does the child keep his/her mouth opened a } \\
\text { lot? } \\
\begin{array}{llll}\text { ( ) Yes } & \text { ( ) No } & \text { ( ) Sometimes }\end{array}\end{array}$ & \\
\hline
\end{tabular}

Based on the literature ${ }^{10-12}$

Figure 2. Questionnaire provided to teachers

The questionnaire was provided to parents through the scrapbook that children use at school, and it was handed over to the teachers who are in the early childhood education program of the institute. Parents who agreed to participate in the study had 15 days to answer to the questionnaire and to return it with the FICT signed as required. On the other hand, the teachers who accepted to participate in the study had 60 days to complete the questionnaires, since some teachers had more than one class. At the end, 238 questionnaires were returned; however, 17 were excluded according to the exclusion criteria of this study, totaling 221.

Data collection lasted from March to November 2017. The non-parametric Chi-square tests and, when required, Fisher's exact test, were used to evaluate the relationship between the variables. The McNemar's test was used to compare the responses provided by parents and teachers using The SAS System for Windows, v9.4, and the SAS Institute Inc, 2002-2008,
Cary, NC, USA. The study used $5 \%$ as significance level.

\section{RESULTS}

The results presentation was divided into three parts: 1. Data collected through the analysis of the questionnaires provided to parents and/or guardians of the children in the institution; 2. Descriptive data collected from the questionnaires provided to the teachers of the institution; and 3. Comparison of the data from both questionnaires (parents and teachers).

\section{Data from the questionnaires answered by the parents:}

The questionnaire provided to the parents included questions regarding pregnancy, childbirth, breastfeeding, the age at which the child started walking and talking. In addition, the questionnaire included 9 
questions that addressed the use of deleterious oral habits, eating habits and breathing pattern. 221 (52.5\%) questionnaires were answered by the parents, whose children presented the following profile: 115 (52.04\%) of the participants were male and 106 (47,96\%) were female. Regarding the age groups, 30 (13.57\%) were up to 3 years old, while 70 (31.67\%) were $3-4$ years old, $59(26.70 \%)$ were $4-5$ years old and $62(28.05 \%)$ were more than 5 years old.

Regarding maternal age, 103 (46.61\%) mothers were between 20-30 years old and 90 (50.25\%) were between 30-40 years old. Regarding education level, 101 (51.79\%) mothers and 105 (61.05\%) parents completed high school, respectively.

One of the questions in the questionnaire was related to breastfeeding. 201 (90.95\%) of the 221 questionnaires answered reported that the children were breastfed and 20 (9.05\%) were not. On the duration of the breastfeeding, $60(30.30 \%)$ children were breastfed for less than six months, 70 (35.35\%) for a period longer than six months, $18(9.09 \%)$ for one year and six months and $50(25.25 \%)$ for more than 2 years. Twenty-three mothers did not answer to this question.

When analyzing the duration of breastfeeding with some deleterious oral habit by the child, it can be noticed that the higher the breastfeeding period, the lower the occurrence of the use of pacifiers and bottle feeding, and the results were statistically significant (Table 1).

Still with respect to deleterious oral habits, 115 (52.04\%) children were bottle-fed, while 53 (24.09\%) used a pacifier, 15 (6.82\%) were thumb-sucking children, and 47 (21.36\%) used to bite their own nails (onychophagy).

Table 1. Duration of breastfeeding and oral habits by children, according to parents

\begin{tabular}{|c|c|c|c|c|c|c|c|c|}
\hline \multirow{2}{*}{ Breastfeeding } & \multicolumn{2}{|c|}{ Baby bottle } & \multirow{2}{*}{ Total } & \multirow{2}{*}{ p-valor } & \multicolumn{2}{|c|}{ Pacifier } & \multirow{2}{*}{ Total } & \multirow{2}{*}{$p$-value } \\
\hline & Yes & No & & & Yes & No & & \\
\hline$<6$ months & 38 & 22 & 60 & \multirow{3}{*}{$0.0134^{*}$} & 25 & 35 & 60 & \multirow{3}{*}{$<0.0001^{*}$} \\
\hline$>6$ months & 61 & 77 & 138 & & 20 & 118 & 138 & \\
\hline Total & 99 & 99 & 198 & & 45 & 153 & 198 & \\
\hline
\end{tabular}

(Fisher Exact test ${ }^{*}$ Chi-Square Test. P-value $0.0134^{*}$ and $<0.0001^{\star}$ )

Although data are not statistically significant, when comparing the use of deleterious oral habits regarding gender, it can be noticed that there was a greater number of female children with these habits, such as: thumb-sucking, onychophagy and pacifier use, while male children presented higher frequency of baby bottle use. Thumb-sucking was the only deleterious habit in which data were statistically significant.
Another question addressed in the questionnaire provided to the parents was related to food. According to them, $34(15.81 \%)$ children had feeding complaints, of which 24 were male and 10 female, and the data were statistically significant (Table 2).

Table 2. Children's gender and occurrence of deleterious oral habits and feeding complaints, according to parents

\begin{tabular}{|c|c|c|c|c|c|c|c|c|}
\hline \multirow{2}{*}{ Gender } & \multicolumn{2}{|c|}{ Thumb-sucking } & \multirow{2}{*}{ Total } & \multirow{2}{*}{ p-valor } & \multicolumn{2}{|c|}{ Queixa Alimentar } & \multirow{2}{*}{ Total } & \multirow[b]{2}{*}{ p-value } \\
\hline & Yes & No & & & Yes & No & & \\
\hline Male & 4 & 110 & 114 & & 24 & 89 & 113 & \\
\hline Female & 11 & 95 & 106 & $0.0434^{*}$ & 10 & 92 & 102 & $0.0218^{*}$ \\
\hline Total & 15 & 205 & 220 & & 34 & 181 & 215 & \\
\hline
\end{tabular}

(Fisher Exact test/* Chi-Square Test. P-value $0.0434^{*}$ and $0.0218^{\star}$ ) 
Regarding the type of complaint, 30 (68.18\%) children refused some food, $5(11.36 \%)$ used to vomit during or after the meal, 5 (11.36\%) had food allergy, and 4 (9.09\%) started choking during feeding.
When relating the presence of deleterious oral habits and age, the data were statistically significant for pacifier and bottle feeding, and a greater number of children in the 3-4 years old age group used these objects (Table 3 ).

Table 3. Children's age range and occurrence of deleterious oral habits, according to parents

\begin{tabular}{|c|c|c|c|c|c|c|c|c|}
\hline \multirow{2}{*}{ Age } & \multicolumn{2}{|c|}{ Baby bottle } & \multirow{2}{*}{ Total } & \multirow{2}{*}{ p-valor } & \multicolumn{2}{|c|}{ Pacifier } & \multirow{2}{*}{ Total } & \multirow{2}{*}{$\mathrm{p}$-value } \\
\hline & Yes & No & & & Yes & No & & \\
\hline Up to 3 years old & 21 & 9 & 30 & & 11 & 19 & 30 & \\
\hline 3-4 years old & 46 & 24 & 70 & & 27 & 43 & 70 & \\
\hline $4-5$ years old & 27 & 32 & 59 & $0.0004^{*}$ & 9 & 49 & 58 & $0.0002^{*}$ \\
\hline$>5$ years old & 21 & 41 & 62 & & 6 & 56 & 62 & \\
\hline Total & 115 & 106 & 221 & & 53 & 167 & 220 & \\
\hline
\end{tabular}

(Chi-Square Test/*Fisher Exact test. P-value $0.0004^{\star}$ and $0.0002^{\star}$ )

With respect to the occurrence of snoring during sleep, 52 (23.64\%) parents reported that children snored while sleeping, but no statistically significant relation was noticed regarding gender; however, a greater number of male children reported such a complaint.

$37(16.74 \%)$ children remained with their mouth opened systematically, while $61(27.60 \%)$ remained with their mouth opened non-systematically, and there was a higher occurrence in female children.

\section{Descriptive data collected from the questionnaires provided to the teachers of the institution:}

The questionnaire provided for teachers had the same questions regarding oral habits, feeding habits and breathing pattern of the questionnaire provided for parents. The group responded to 221 questionnaires according to the groups.

With regard to deleterious oral habits, the researches noticed that the pacifier was the most common habit, representing $45(20.36 \%)$ children, followed by the use of the bottle 17 (7.69\%), onychophagy 14 (6.33\%), and snoring 12 (5.43\%). With respect to remaining with the mouth opened, 12 (5.43\%) children presented such a habit systematically, while $40(18.10 \%)$ had this habit in a non-systematic way.

Regarding feeding complaints, teachers reported that $31(14.03 \%)$ children had such complaints, and food refusal was also mentioned by professionals as the most representative, representing 28 (82.35\%) children.

\section{Comparison of the data from questionnaires provided to parents and teachers:}

When comparing the responses of both groups with the McNemar's test, the p-value was statistically significant meaning the answers provided by parents and teachers were not similar with respect to the use of baby bottle, onychophagy, and snoring. In addition, the parents noticed the occurrence of deleterious oral habits in a greater frequency when compared to teachers (Table 4). 
Table 4. Comparison of the questionnaires provided to parents and teachers on the use of baby bottle, onychophagy and snoring

\begin{tabular}{|c|c|c|c|c|c|c|c|c|c|c|}
\hline \multirow{2}{*}{$\begin{array}{l}\text { Baby bottle } \\
\text { Parents }\end{array}$} & \multicolumn{2}{|c|}{$\begin{array}{l}\text { Baby bottle } \\
\text { Teachers }\end{array}$} & \multirow{2}{*}{ Total } & \multicolumn{2}{|c|}{ Onychophagy } & \multirow{2}{*}{ Total } & \multicolumn{2}{|c|}{ Snoring } & \multirow[t]{2}{*}{ Total } & \multirow{2}{*}{$p$-value } \\
\hline & Yes & No & & Yes & No & & Yes & No & & \\
\hline Yes & 15 & 100 & 115 & 7 & 40 & 47 & 7 & 45 & 52 & \\
\hline No & 2 & 104 & 106 & 7 & 166 & 173 & 5 & 162 & 167 & $<0.0001^{*}$ \\
\hline Total & 17 & 204 & 221 & 14 & 206 & 220 & 12 & 207 & 219 & \\
\hline
\end{tabular}

(McNemar's test - Symmetry. P-value: $<0.0001^{\star}$ )

The data regarding keeping the mouth opened were not described in the table, but they were also statistically significant, which shows a discrepancy between the responses of parents and teachers.

\section{DISCUSSION}

Deleterious oral habits can lead to impairments in speech articulation, sucking, chewing and swallowing.

It is known that exclusive breastfeeding in the first six months of life is of great importance for the development of the baby. In this study, 201 (90.95\%) of the 221 questionnaires answered were breastfed, 70 $(35.35 \%)$ of these were breastfed for more than six months, as stated by the World Health Organization (WHO), which advises mothers to breastfeed their children exclusively during the first six months of life, in order to enable a correct psychological and physiological development ${ }^{13}$. In addition, it is known that the bond between mother and baby is strengthened during breastfeeding.

On the other hand, 60 (30.30\%) children were breastfed for a less than six months. The reasons for early weaning from breastfeeding were not addressed in this study; however, the literature describes some factors that may influence this decision, such as: lack of confidence to breastfeed, feeling depressed after giving birth, pain, and concerns on returning to the labor market ${ }^{14}$.

With regard the period of exclusive breastfeeding, the findings of this study corroborate with other studies, which report values between $25.3 \%$ and $75 \% 15,16$. However, these rates in Brazil are still considered low, although in recent years there has been a resumption regarding the importance of exclusive breastfeeding, some authors ${ }^{17}$ reported that the prevalence in the country is $60.7 \%$ in the first 30 days and that this number decreases over the months.

Exclusive breastfeeding is important and some studies ${ }^{17,18}$ associate it with decreasing deleterious oral habits in children who exclusively breastfed for more than six months. It can be noted in this study that the duration of breastfeeding impacted on pacifier and bottle feeding habits.

Still on the occurrence of deleterious oral habits, it was noticed that more than half of the children included in the sample $(52.04 \%)$ used baby bottles, which was followed by the use of pacifiers (24.09\%), onycophagy $(21.36 \%)$, and thumb-sucking (6.82\%). The data corroborate some studies, ${ }^{19,20}$ although they disagree with other studies ${ }^{9,21}$ which report a higher occurrence of pacifier use. As to its use being greater than other deleterious oral habits, it can be concluded that it is due to the fact that it is included in the layette of the pregnant women and it is layette as something cultural, since many relatives insist on offering it to the baby in the first days of life.

Another aspect that was relevant during the analysis of the data was the occurrence, of a greater number of bottle-feeding cases in the children evaluated, given that this habit should not be included from 18 months of age on, during which the child begins to introduce a greater number of solid foods, besides drinking in the glass. The prolonged use of the baby bottle may cause changes in the functions of sucking, swallowing, chewing, also contributing to the formation of malocclusions ${ }^{22}$. The tongue remains on the oral floor when sucking the tip of the baby bottle, working only as a dispenser for the milk introduced in the mouth and it tends to become hypofunctioning over time, and the tongue may assume an anterior position in the oral cavity. In addition, many children use the baby bottle at night, usually before bedtime, and parents tend to sweeten the child's milk; thus, the lack of hygiene and the fermentation of this sugar in the mouth, over time, leads to the so-called "night bottle caries" 22 .

Regarding gender, this study reported a greater use of pacifiers, thumb-sucking and onychophagy by girls, while the use of baby bottles was higher for boys, 
such findings were also found by other authors ${ }^{23}$. With respect to gender and the habit of keeping the mouth opened, which is associated with oral breathing, a greater occurrence was observed in the female sex, a fact that was also described in another study ${ }^{12}$.

When associating the presence of habit in relation to the age group, significant results were obtained regarding the use of pacifiers and baby bottle, reporting a higher occurrence of these habits in the age group from 3 to 4 years of age, and the results corroborate with another research ${ }^{24}$. In another study ${ }^{25}$ conducted with children from 0 to 5 years of age, the prevalence of pacifier use was $68.1 \%$, and $49.3 \%$ of the children used this object at the time of the study. In addition, nine out of every ten children reported using baby bottle, showing that this is a common habit in childhood.

One of the questions asked to the parents in this study was on feeding complaints, and 34 (15.81\%) children had some complaint, with the food refusal as the most frequent. Regarding gender, the data were significant for male children.

Regarding childhood feeding issues, some authors ${ }^{26}$ report that such complaints are common and that studies conducted all over the world shows that food refusal is among the most frequent. According to the study ${ }^{26}$, of the 984 families analyzed by IPSOS Health Care, approximately $50 \%$ of reports of feeding issues were from preschoolers.

Of the 115 children who used baby bottle in this study, 64 were boys. Some authors have reported ${ }^{27}$ that culture related to genres would influence the decision of the mothers to interrupt breastfeeding in boys first, which would lead to greater use of baby bottles by them. It would be related to the feeding complaint, considering that prolonged use of baby bottle may lead to decreased chewing and preference for liquid and pasty food.

Comparing the perspective of parents and teachers on the use of deleterious oral habits, it can be noticed that parents refer more to their presence than teachers.

A study ${ }^{28}$ conducted with a group of parents found that although they knew the harm caused by the overuse of oral habits, such as pacifiers, most of them already offered such an object to their children. On the other hand, another study ${ }^{29}$, which was conducted with students with specialization in early childhood education, reported that most professionals believed that the use of baby bottle and pacifier by children was normal. The study group reported interest in knowing more about the subject, showing the importance of the implementation of strategies for school health promotion and prevention.

\section{CONCLUSION}

According to the present study, the occurrence of deleterious oral habits in preschool children is common. In the studied group, the parents reported a higher number of deleterious oral habits when compared to that reported by teachers. Harmful oral habits, such as the use of pacifiers and baby bottles, may cause many problems, and parents and teachers must be aware, so that different strategies to avoid them can be conducted, especially in the school environment, avoiding the losses of their overuse.

\section{REFERENCES}

1. Boeck EM, Pizzol KEDC, Barbosa EGP, Pires NCA, Lunardi N. Prevalência de má oclusão em crianças de 3 a 6 anos portadoras de hábito de sucção de dedo e/ou chupeta. Rev. Odontol. UNESP. [Internet]. 2013 Apr [last accessed July 11, 2018]; 42(2): 110-6. Available at: http://www.scielo. $\mathrm{br} / \mathrm{scielo}$.php?script $=$ sci_arttext\&pid $=$ S180725772013000200008\&lng=en

2. Garde JB, Suryavanshi RK, Jawale BA, DeshmukhV, Dadhe DP, Suryavanshi MK. An epidemiological study to know the prevalence of deleterious oral habits among 6 to 12 year old children. J Int Oral Health. 2014;6(1):39-43.

3. Suhani RD, Suhani MF, Muntean A, Mesaros M, Badea ME. Deleterious oral habits in children with hearing impairment. Clujul Medical. 2015;88(3):403.

4. Sharma S, Bansal A, Asopa K. Prevalence of oral habits among eleven to thirteen years old children in Jaipur. Int J Clin Pediatr Dent. 2015;8(3):208.

5. Maffei MS, Souza RS, Mello AS, Souza JGMV, Ceranto-Boleta DCF. Relação do desmame precoce com hábitos bucais deletérios na primeira infância. Odontol. Clín.-Cient. 2016;15(4):253-8.

6. Carvalho CM, Carvalho LFPC, Forte FDS, Aragão MS, Costa LJ. Prevalência de mordida aberta anterior em crianças de 3 a 5 anos em Cabedelo/ PB e relação com hábitos bucais deletérios. Pesq Bras Odontoped Clin Integ. [Internet]. 2009 Ago [last accessed July 11, 2018];9(2):205-10. Available at: http://dx.doi.org/10.4034/1519.0501.2009.0092. 0012

7. Lamounier JA. O efeito de bicos e chupetas no aleitamento materno. J. Pediatr. 2003;79(4):284-6. 
8. Wolff GS, Goulart BNG. Percepção dos pais sobre os distúrbios fonoaudiológicos na infância. Rev. bras. crescimento desenvolv. hum. [Internet] 2013 [last accessed: July 11, 2018]; 23(2):177-83. Available at: http://pepsic.bvsalud.org/scielo.php?script $=$ sci $_{-}$ arttext\&pid=S0104-12822013000200009\&lng =pt\& $\mathrm{nrm}=\mathrm{iso}$

9. Garbin CAS, Garbin AJl, Martins RJ, Souza NP, Moimaz SAS. Prevalência de hábitos de sucção não nutritivos em pré-escolares e a percepção dos pais sobre sua relação com mal oclusões. Ciênc. saúde coletiva. [Internet] 2014 [last accessed Jun 17, 2018]; 19(2):553-8. Available at: http://www.scielosp. org/scielo.php?script $=$ sci_ $\quad$ arttext\&pid $=$ S1413$81232014000200553 \&$ Ing $=$ en. http:// dx.doi. org/10.1590/1413-81232014192.23212012

10. Galvão ACUR, Menezes SFL, Nemr K. Correlação de hábitos orais deletérios entre crianças de 4:00 a 6:00 anos de escola pública e escola particular da cidade de Manaus-AM. Rev. CEFAC. 2006;8(3):328-36.

11. Carminatti M, Lavra-Pinto $B$, Franzon $R$, Rodrigues JÁ, Araújo FB, Gomes E. Impacto da cárie dentária, maloclusão e hábitos orais na qualidade de vida relacionada à saúde oral em crianças pré - escolares. Audiol., Commun. Res. [Internet]. 2017 [last accessed Dec 02, 2018]; 22:e1801. Available at: http://www.scielo. $\mathrm{br} /$ scielo. .php? script $=$ sci_arttext\&pid $=$ S231764312017000100327\&Ing=en. Epub Sep 21, 2017. http://dx.doi.org/10.1590/2317-6431-2016-1801

12. Melo PED, Pontes JRS. Deleterious oral habits in a group of children from a public school in Sao Paulo city. Rev. CEFAC [serial on the Internet]. 2014 Dez [last accessed Apr 30, 2018]; 16(6):1945-52. Available at: http://www.scielo. $\mathrm{br} /$ scielo.php?script $=$ sci_arttext\&pid $=$ S151618462014000601945\&lng=en. http://dx.doi. org/10.1590/1982-0216201418213

13. Brasil. Ministério da Saúde. Saúde da criança: nutrição infantil: aleitamento materno e alimentação complementar. 2009. [last accessed July 11, 2018]. Available at: http://bvsms.saude.gov.br/bvs/ publicacoes/saude_crianca_nutricao_aleitamento_ alimentacao.pdf

14. Primo CC, Nunes BP, Lima EFA, Leite FMC, Pontes $M B$, Brandão MAG. Which factors influence women in the decision to breastfeed? Invest Educ Enferm. 2016;34(1):198-210.
15. Gallarreta FWM, Silva AMT, Toniolo IMF. Tipo e duração de aleitamento e sua relação com o hábito de sucção da chupeta e a oclusão. JBP - j. bras. odontopediatr. odontol. bebê. 2004;7(40):552-8.

16. Praetzel JR, Saldanha MJ, Pereira JES, Guimarães MB. Relação entre o tipo de aleitamento e o uso de chupeta. JBP - J. bras. odontopediatr. odontol. bebê. 2002;5(25):235-40.

17. Primo CC, Massoroni L, Lima RCD, Forechi L, Capucho BL. Fatores que interferem na amamentação exclusiva. Rev. Bras. Pesq. Saúde. 2017;19(1): 108-13.

18. Oliveira MMB de, Silva IA, Gregório JAB, Gregório EP. Associação entre aleitamento materno, hábitos orais deletérios e alterações de motricidade orofacial em pacientes sob intervenção ortodôntica Rev. iberoam. educ. invest. enferm. [Internet]. 2015 [last accessed July 13, 2018]; 5(3): 8-14. Available at: http://www.enfermeria21.com/revistas/aladefe/ articulo/168/

19. Silvério KCA, Ferreira APS, Johanns CM, Wolf A, Furkim AM, Marques JM. Relação de escolaridade, faixa etária e profissão de mães com a oferta de chupeta e mamadeira a seus filhos. Rev. CEFAC. 2012;14(4):610-5.

20. Matos GC, Santos JC, Granzotti-Guedes RB, Silva $\mathrm{K}$, Baldrighi SEZM, Cesar CPHAR. The prevalence of oral habits in preschoolers. Distúrb. Comun. 2017;29(1):68-76.

21. Pereira MR, Jardim LE, Figueiredo MC, FaustinoSilva DD. Prevalência de maloclusão em crianças de quatro anos de idade e fatores associados na atenção primária à saúde. Stomatos. 2017;23(45):49-58.

22. Lopes AR. Alterações bucais causadas pelo uso prolongado de chupeta e mamadeira em crianças [Trabalho de conclusão de curso]. Minas Gerais (MG): Universidade Federal de Minas Gerais, Especialização em Atenção Básica em Saúde da Família; 2010.

23. Pizzol KEDC, Montanha S, Fazan ET, Boeck EM, Rastelli ANS. Prevalência dos hábitos de sucção não nutritiva e sua relação com a idade, gênero e tipo de aleitamento em pré-escolares da cidade de Araraquara. Rev. CEFAC [Internet]. 2012 June [last accessed Apr 30, 2018]; 14(3):506-15. Available at: $\quad$ http://www.scielo.br/scielo.php?script $=$ sci_ arttext\&pid $=$ S1516-18462012000300015\&lng $=$ en. Epub Jan 09, 2012. http://dx.doi.org/10.1590/ S1516-18462012005000001 
24. Góes MPS, Araújo CMT, Góes PSA, Jamelli SR. Persistência de hábitos de sucção não nutritiva: prevalência e fatores associados. Rev. Bras. Saude Mater. Infant. [Internet]. 2013 Sep [last accessed May 01, 2018]; 13(3):

247-257. Available at: http://www.scielo.br/ scielo.php? script $=$ sci_arttext\&pid $=$ S151938292013000300006\&lng=en. http://dx.doi. org/10.1590/S1519-38292013000300006

25. Ferreira-Vargas F, Senna RA, Ilha MC, Figueiró P, Feldens CA, Kramer PF. Uso de chupeta em pré-escolares do sul do Brasil: prevalência e fatores associados. RFO UPF. 2018;23(2):144-9.

26. Almeida CN, Mello ED, Maranhão HS, Vieira MC, Barros R, Barreto JR et al. Dificuldades alimentares na infância: revisão da literatura com foco nas repercussões à saúde. Pediatria Moderna. 2012;48(9):24-6.

27. Pérez-Escamilla R, Lutter C, Segall AM, Rivera A, Treviño-Siller S, Sanghvi T. Exclusive breast-feeding duration is associated with attitudinal, socieconomic and biocultural determinants in three Latin American countries. J Nutr. 1995;125(12):2972-84.

28. Garbin CAS, Garbin AJl, Martins RJ, Souza NP, Moimaz AS. Prevalência de hábitos de sucção não nutritivos em pré-escolares e a percepção dos pais sobre sua relação com maloclusões. Ciência \& Saúde Coletiva [Internet]. 2014, [last accessed July 13, 2018] 19(2):553-8. Available at: $\quad$ http://www.scielo.br/scielo.php?script $=$ sci_ arttext\&pid $=$ S1413-81232014000200553\&Ing $=\bar{p}$ t\&tlng =pt. ISSN 1678-4561. https://doi. org/10.1590/1413-81232014192.23212012

29. Brant MO, Cavalcanti L, Auad SM, Paiva SM, Pordeus IA, Serra-Negra JM. The perception of graduate students in early childhood education regarding the oral habits of preschoolers. Arq. Odontol. [Internet]. 2016 Mar [last accessed: July 13, 2018] ; 52(1): 06-12. Available at: http:// revodonto.bvsalud.org/scielo.php?script $=$ sci_ arttext\&pid=S1516-09392016000100001\&lng $=$ en 